\title{
ラット前脛骨筋および腓腹筋支配 運動神経細胞の脊髄内局在
}

\author{
長崎記念病院整形外科 \\ 中村昌一・井手迪 \\ 長崎大学整形外科 \\ 伊 藤 信 之・岩 崎 勝 郎
}

The Location of Motoneurons of the Tibialis Anterior Muscle and Gastrocunemius Muscle in the Spinal Cord of the Rat.

by

Masakazu Nakamura and Susumu Ide

Department of Orthopaedic Surgery, Nagasaki Memorial Hospital

Nobuyuki Ito and Katuro Iwasaki

Department of Orthopaedie Surgery, School of medicine, Nagasaki University

The locations of motoneurons of the tibialis anterior muscle and the gastrocunemius muscle in the rat spinal cord have been determined by using retrograde transport of the horseradish peroxidase.

The horseradish peroxidase was injected into tibialis anterior muscle on right side and gastrocunemius muscle on left side. At $24 \sim 48$ hours after injection, the spinal cord was removed, and the serial coronal sections were cut at $100 \mu \mathrm{m}$ and stained with diaminobenzidine. The number of the labeled motoneuron were analyzed bilaterally.

Following results were obtained: Most of the labeled motoneuron of the tibialis anterior muscle and the gastrocunemius muscle were distributed throughout $\mathrm{L}_{4}$ and $\mathrm{L}_{5}$ respectively with significant difference $(\mathrm{p}<0.01)$.

The labeled motoneurons of tibialis anterior muscle were located in more ventral side than that of gastrocunemius muscle $(p<0.01)$.

\section{は じめに}

脊柱管内病変の高位診断に際して, 神経根脱落症状 は有力な指標となる．このため各筋群を支配する運動 神経細胞の脊髄内の局在を明らかにすることは意義が あろう。

Horseradish Peroxidase (HRP) が軸索内を逆 行性に輸送される特性を利用して，これまで種々の筋 肉を支配する motoneuronの脊髄内の局在を確かめ る研究が行なわれてきた。しかしこれらの研究は本邦 ではラット後肢筋に関するものは少なく，また報告さ
れたものはすべて脊髄横断切片によるものである.こ のため筋肉を支配する motoneuron の高位分布の決 定が明確にはなされにくい. 今回の実験では春髄の冠 状断切片を作製することにより，目的とする筋の運動 神経細胞の正確な高位分布が決定可能となった，本実 験の目的は, ラット前脛骨筋拉よび腓腹筋支配運動神 経細胞の脊髄前角内における局在を, 冠状断切片を作 製し明確にすることである.

\section{材料および方法}

材料: 生後 $5 \sim 8$ 週令の雄 Wistar 系ラット 12 匹 


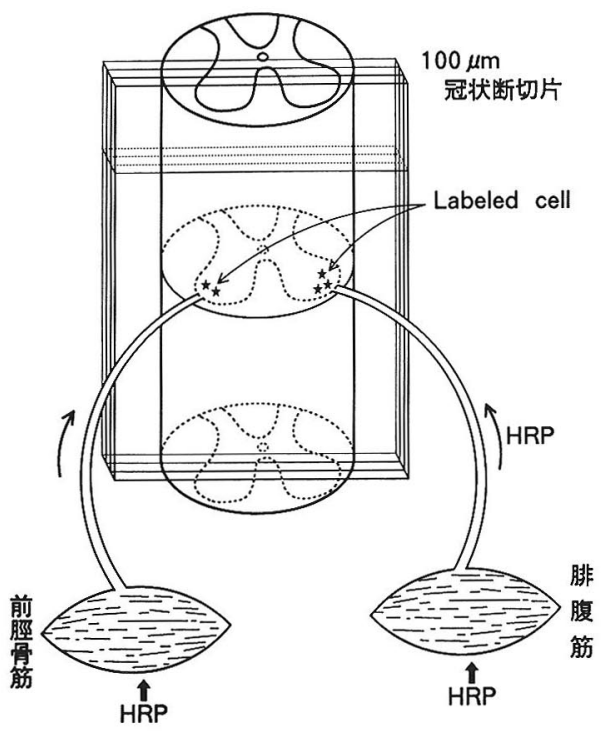

図1 実験方法のシェーマ

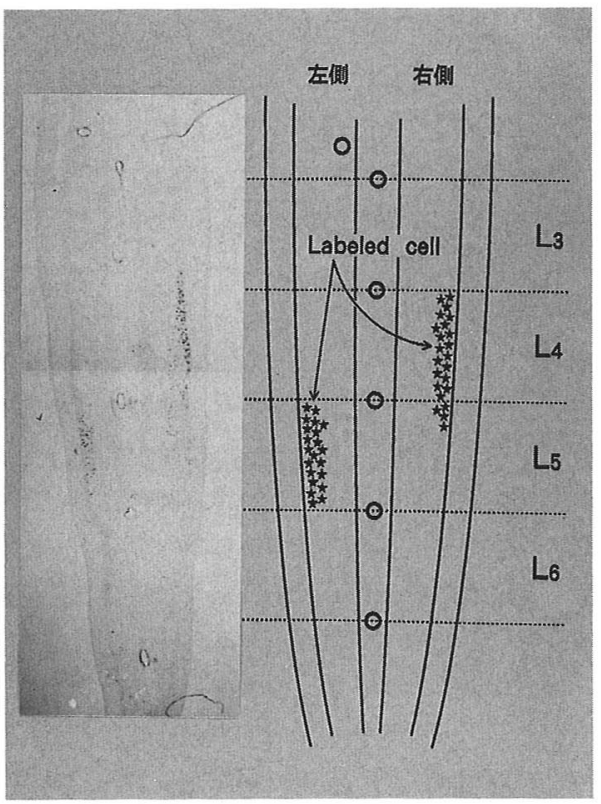

図2 左: 脊骵冠状断切片 $(\times 15)$ 右: 左図のシェーマ

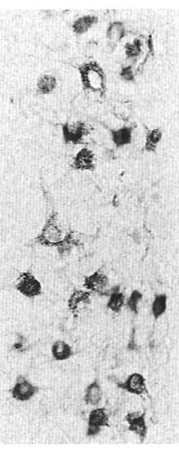

(A)

(B)

図 3 染色細胞の強拡大像

A : $(\times 50) \quad$ B : $(\times 200)$

染色細胞数

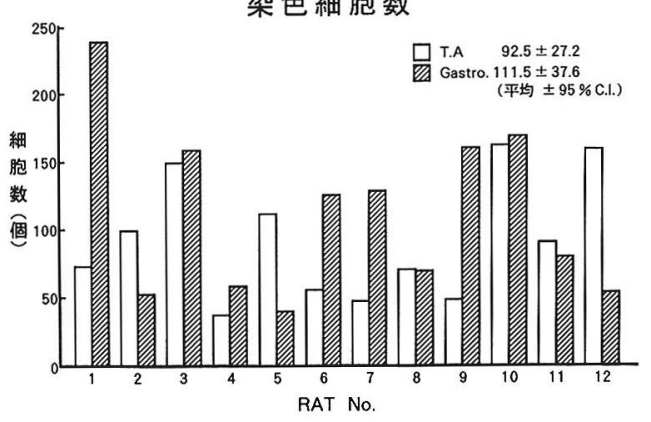

図 4 各例における染色細胞総数を示す.

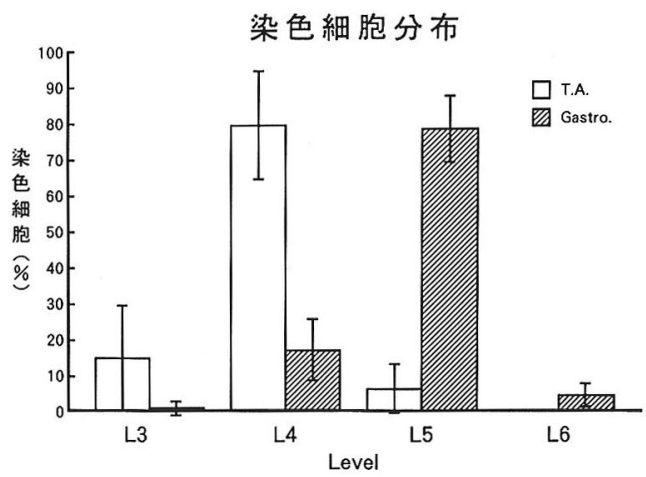

図 5 各䯣節レベルにおける染色細胞の割合を示寸. 前脛骨筋では $\mathrm{L}_{4}$, 腓腹筋では $\mathrm{L}_{5}$ を中心に分布 している. 


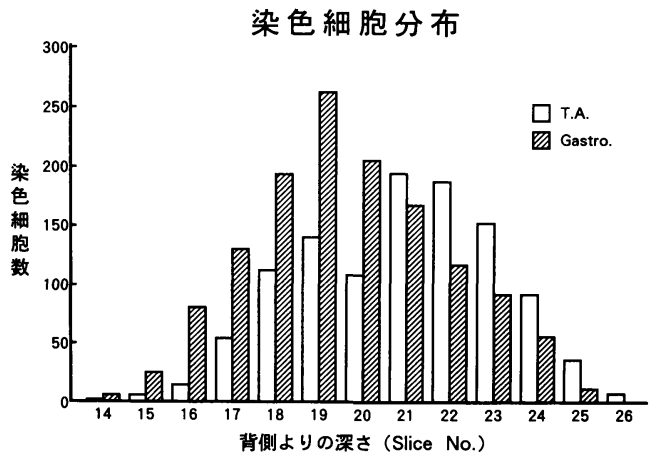

図6 各切片における染色細胞総数を示す. 切片は背側より順次作製した。

を使用した。

方法 : 一側の前脛骨筋および対側の腓腹筋に直視下 に HRP（東洋紡 Typel-c）を 1250-2500 I. U. 注入 した. 24〜48 時間後，ケタラール麻酔下で左心室に エラス夕針を挿入し右心耳を切開して生理食塩水 500 cc で灌流脱血した．その後，50\%グルタールアルデ ヒド含有 $0.2 \mathrm{~mol}$ 燐酸緩衝液（PBS） $1000 \mathrm{cc}$ で固定, $\mathrm{L}_{3} \sim \mathrm{L}_{6}$ の髄節を鏡視下に展開し一塊として切り出し た. 左右および各髄節の指標には墨汁によるマーキン グを行なった. PBSに 24 時間浸透し，ドライアイス を用いて標本を凍結させた後, $100 \mu \mathrm{m}$ の連続冠状断 切片を作製した。これにDiaminobenzidine 染色を 行ない, 両側の染色前角細胞（以後染色細胞と記す） を計数した (図 1). なお染色細胞は, 解剖学的に形 態の明らかなもの, 特に核の輪郭が明瞭なものを染色 された前角細胞とし，この数を求めた，HRP 注入時 には周辺の筋肉に漏出がない樣に注意を払った。また 脊髄の形態を考慮し，左右が同じ深さになるように背 側より順次切片を作成した. 図 2 に実際の標本とその シェーマを示す。一番上のマークが左側を示し, HRP が腓腹筋に注入された側である. 中央側のマークはそ れぞれ $\mathrm{L}_{2} \sim \mathrm{L}_{6}$ 神経根の脊髄分岐部を示す. 脊髄の両 側に暗褐色に濃く染まっているのが染色細胞であり, この例では, 前脛骨筋側が $\mathrm{L}_{4}$ および $\mathrm{L}_{5}$ の一部, 腓腹 筋側が $L_{5}$ に分布しているのがわかる。図 3 に染色細 胞の強拡大像を示す．細胞中央の抜けたように見える のが核であり, 細胞体内の顆粒, 樹状突起等も観察さ れる.このような細胞を染色細胞とし，その個体差,
脊髄高位別および深度別の分布を，前脛骨筋と腓腹筋 間で比較した。

$$
\text { 結果 }
$$

各例の染色細胞の総数は, 前脛骨筋では 38〜162 個, 腓腹筋では 40 2 239 個であり，その平均と $95 \%$ 信頼 区間はそれぞれ $92.5 \pm 27.2 ， 111.5 \pm 37.6$ 個であった (図 4 ).

$\mathrm{L}_{3} \sim \mathrm{L}_{6}$ 各髄節における染色細胞数の総数に対する 割合を図 5 に示す. その平均 $95 \%$ 信頼区間は，前脛 骨筋では， $\mathrm{L}_{3} 14.8 \pm 14.7, \mathrm{~L}_{4} 79.1 \pm 15.0, \mathrm{~L}_{5} 6 \pm$ $6.8 \%$, 腓腹筋では $\mathrm{L}_{3} 0.9 \pm 2.0, \mathrm{~L}_{4} 16.7 \pm 8.5, \mathrm{~L}_{5}$ $78.2 \pm 9.2, \mathrm{~L}_{6} 4.2 \pm 3.2 \%$ であった。前脛骨筋では $\mathrm{L}_{4}$, 腓腹筋では $\mathrm{L}_{5}$ 中心に分布しており， $\mathrm{L}_{4}$ と $\mathrm{L}_{5} に$ はそれぞれ両筋の染色細胞を認めた. 統計学的に $\mathrm{L}_{4}$ および $\mathrm{L}_{5}$ では，両筋の染色細胞数に有意差を認め $(\mathrm{p}<0.01)$, 前脛骨筋および腓腹筋支配運動神経細胞 の脊髄前角内における局在は一髄節のズレがあること が明らかとなった。

さらに，前脛骨筋および腓腹筋支配運動神経細胞の 分布深度について検討した. 前脛骨筋は背側より 1426 枚目の切片に分布しそのピークは 21-23 枚目, 腓 腹筋では 14-25 枚目に分布しピークは18-21枚目であっ た. 統計学的に有意差を認め $(p<0.01)$, 前脛骨筋支 配運動神経細胞が腓腹筋のそれより腹側にあることが わかった（図6).

\section{考察 \\ ニューロンの軸索突起内を物質が移動する現像を軸} 索流といい, ニューロンの成長・維持・老化・変性・ 再生・シナプス機能の維持と密接に関連している．軸 索流にはニューロンの細胞体から軸索末端へ向かう順 行性（下行性）の流れと, 軸索末端から細胞体へ向か う逆行性 (上行性) の流れがある. HRPは, 軸索末 端においてエンドサイトーシスによってとりこまれ， 多少胞体 (Multivesicular bodies) にふくまれた形 で軸索をさかのほり細胞体に到着する ${ }^{3)}$ 6)。この特性 を利用して motoneuron を組織学的に固定する方法 が, Kristensson の報告 ${ }^{5)}$ 以来主流となり，これま で種々の筋肉を支配する motoneuron の脊䯣内の局 在に関する研究が行なわれてきた. しかしそれらは, 本邦の報告はすべてが, また外国のものも大多数が脊 
䯣横断切片によるものであり, motoneuronの高位 分布の決定が明確にはなされにくい. 今回の実験では 冠状断切片を用いることにより， motoneuron の正 確な高位分布が決定可能となった。

本法による計測結果で, 前脛骨筋と腓腹筋の前角細 胞の分布を明確に同定することができた.すなわち前 脛骨筋は, $\mathrm{L}_{4}$ に約 $80 \%$ と大部分を占め, $\mathrm{L}_{3}, \mathrm{~L}_{5}$ にも一部分布していた。.小西帛は $\mathrm{L}_{3}$ から $\mathrm{L}_{5}$ 近位に 分布しピークは $\mathrm{L}_{4}$ であったと報告し, 和田 ${ }^{8)}$ は $\mathrm{L}_{3}$ 中央部より $\mathrm{L}_{4}$ 尾側に分布していたと報告している. 伊藤 ${ }^{1)}$ は各髄節の割合を $\mathrm{L}_{3}, \mathrm{~L}_{4}, \mathrm{~L}_{5}$ にそれぞれ 20 , 70，10\%であったと記している. 今回の結果はこれら とほほ一致するが, 各髄節の割合についてはより正確 な值が得られたと考える。また腓腹筋では $\mathrm{L}_{5}$ に約 80 $\%$ と大部分を占め, $\mathrm{L}_{3}, \mathrm{~L}_{4}, \mathrm{~L}_{6}$ にも一部分布して いた. 和田 ${ }^{8)}$ は 2 例のラットの研究で, $\mathrm{L}_{3}$ やや尾側 より $\mathrm{L}_{4}$ に分布していると報告したが, 今回の研究と はやや結果が異なっている. 二足歩行をするヒトでは, 前脛骨筋の筋力低下を来す場合 $\mathrm{L}_{4} \cdot \mathrm{L}_{5}$ の障害の例 であり, 腓腹筋の筋力低下を来す場合 S，の障害の例 であり，両筋を支配する motoneuron の髄節分布は 同一ではない. 四足歩行をするラットに当てはまるか 否かは問題であるが, 今回の結果では一髄節の差を認 めた。

脛髄前角の motoneuron の配列には, 体部位局在 性がみられることが知られている2). Sharrard ${ }^{7)}$ はポリオの症例にもとずく報告で, 前脛骨筋支配 の motoneuron は前角内の背外側, 腓腹筋支配の motoneuron は内腹側に位置することを示した。今 回の実験では，その点については詳しく言及できない. しかし前後方向では相違があること, 即ち前脛骨筋支 配の motoneuron は腓腹筋のそれに比し腹側に存在 することが明らかであった. Sharrardの報告とは異 なるが, 体部位局在性がみられることは確認された。
今回の実験の結果は, 脱神経筋内神経幹直接埋没移 植の研究や神経縫合後のミスデイレクションの研究に も応用可能であると考える.

$$
\text { ま と め }
$$

(1)ラット前脛骨筋および腓腹筋支配運動神経細胞の 脊髄前角内における局在を HRP 法を用いて検索した。

(2)前脛骨筋では $\mathrm{L}_{4}$, 腓腹筋では $\mathrm{L}_{5}$ を中心染色 細胞が分布しており，一髄節の相違がみられた。

(3)前脛骨筋の染色細胞は腓腹筋のそれに比し, 腹側 に多く分布していた。

(なお本実験は長崎大学医学部附属動物実験施設に 於て行った.)

\section{参 考 文 献}

1）伊藤信之・他：脱神経筋内神経移植に関する研究一 HRP 法を用いた脊髄前角細胞染色による再神経支配に ついて一. 日手会誌, $7: 70-73,1990$.

2）平松公三郎：ラットの長橈側手根伸筋を支配する運動 神経細胞の局在に関する研究. 長崎医学会雑誌, $58: 208$ -217, 1983.

3）小宮義璋 - 黑川正則（1978）「神経科学講座」（渡辺 · 森田 ·伊藤 - 天野編） $2,37-66$, 理工学社 : 軸索内輸送

4）小西宏昭: Horseradish Peroxidase (HRP) を用い た春髄前角細胞染色による末梢神経機能評価に関する研 究. 日整会誌, $63: 810-818,1989$.

5) Kristensson k., et al.: Retrograde axonal transport of protein. Brain Res., $29: 363-365,1971$.

6）黑川正則：軸索流概観. 眼科 Mook, $9: 114-124$, 金 原出版, 1979.

7) Sharrard, W. J.W.: The distribution of permanent paralysis in the lower limb in poliomyelitis. J. Bone Joint Surg., 37-B : 540-558, 1955.

8）和田英二 : Horseradish Peroxidase (HRP) 法を用 いた再生運動神経の Misdirection に関する研究. 岐阜大 医紀，33：1292-1315，1985. 